\title{
Arrhenius and His Electrified Children
}

\author{
A New Use for High-frequency Currents
}

By John B. Huber, A.M., M.D.

$\mathbf{I}_{\text {Arrhenius, the noted physicist and Nobel prize winner, }}$ has completed in Stockholm a series of experiments proving that the electrical high-frequency current is a marvelous aid to the physical and mental development of school children, "nearly doubling their growth and greatly improving their learning." The sare informed that two groups of children of practically similar age, physique and mentality were placed in two rooms precisely alike, except that in one were wires carrying high-frequency, alternating currents made known by d'Arsonval. Neither the teachers nor the pupils, it is reported, were aware of their exposure to the "magnetic influence."

At the end of six months, runs the report, the electrically charged children had grown an average of 51 millimeters ( 2 inches); while the children not thus charged averaged in growth 31 millimeters (1.16 inches). As to psychism, taking twenty as the standard of perfection, the magnetized children reached in their studies an average of 18.4, while fifteen attained a perfect mark. On the other hand, the unmagnetized children reached an average of 15 , only nine attaining perfect marks. It would seem also that length of days is to be assured these fortunately clectrified children; and the newspaper here referred to begins with impressive quotations from Scripture as to living forever and otherwise more or less relevant to this assurance. The magnetized teachers are said to have attested that their faculties were quickened and their powers of endurance increased. "The experiments undoubtedly will be enlarged; and if the results are verified it is thought that the system will be adopted immediately to aid backward children."

The reflecting scientist may well be skeptical as to the accuracy of these reports. As they stand one may, however, consider them from two viewpoints: That of our present knowledge of the effects of the high-frequency current, and from the biologist's point of view.

High-frequency currents are oscillating condenserdischarge currents, having a rapid rate of alternation, up even to millions per second. These currents are produced usually by the discharge of a condenser, such as a Leyden jar, through a small inductorium in the circuit. The static induced current was discovered by Dr. William J. Morton in 1881, and other workers have since made modifications and have invented appliances loy which the therapeutic value of these currents has been enhanced. There are the high-frequency d'Arsonral oscillator; Tesla's transformer, which Piffard aldapted for the treatment of disease; Oudin's resonator, and so forth.

One is apt to think of the living body (especially his own) as an isolated entity, a something quite distinct from its environment. But this is not absolutely so. The body is anyway nine-tenths water. And it is possible that the electric waves generated by the highelectric waves generated by the high-
frequency current may materialiy though intangibly affect the many millions of cells which make up any individual corporeal life. A species of "molecular gymnastics" is considered to be induced by the infinitely rapid oscillations between plus and minus electricity or a sort of molecular torsion and recovery induced by alternating charges. Thus, it may be claimed, indeed considered even proven, that high frequency currents have had distinctly physiological effects. D'Arsonval has uildoubtedly produced salutary modifications of metabolism by means of high-frequency, high potential currents. And some of the effects pro. duced by him and by others have been unquestionably remedial. In d'Arsonval's experiments more water was given off by the body and more was given off by the body and more
carbonic acid, the ratio in patient and animal being ten, twenty, even thirty per cent. Excess of uric acid is brought down to the normal by excretion, and elimination is markedly furthered.

It may be assumed, then, that

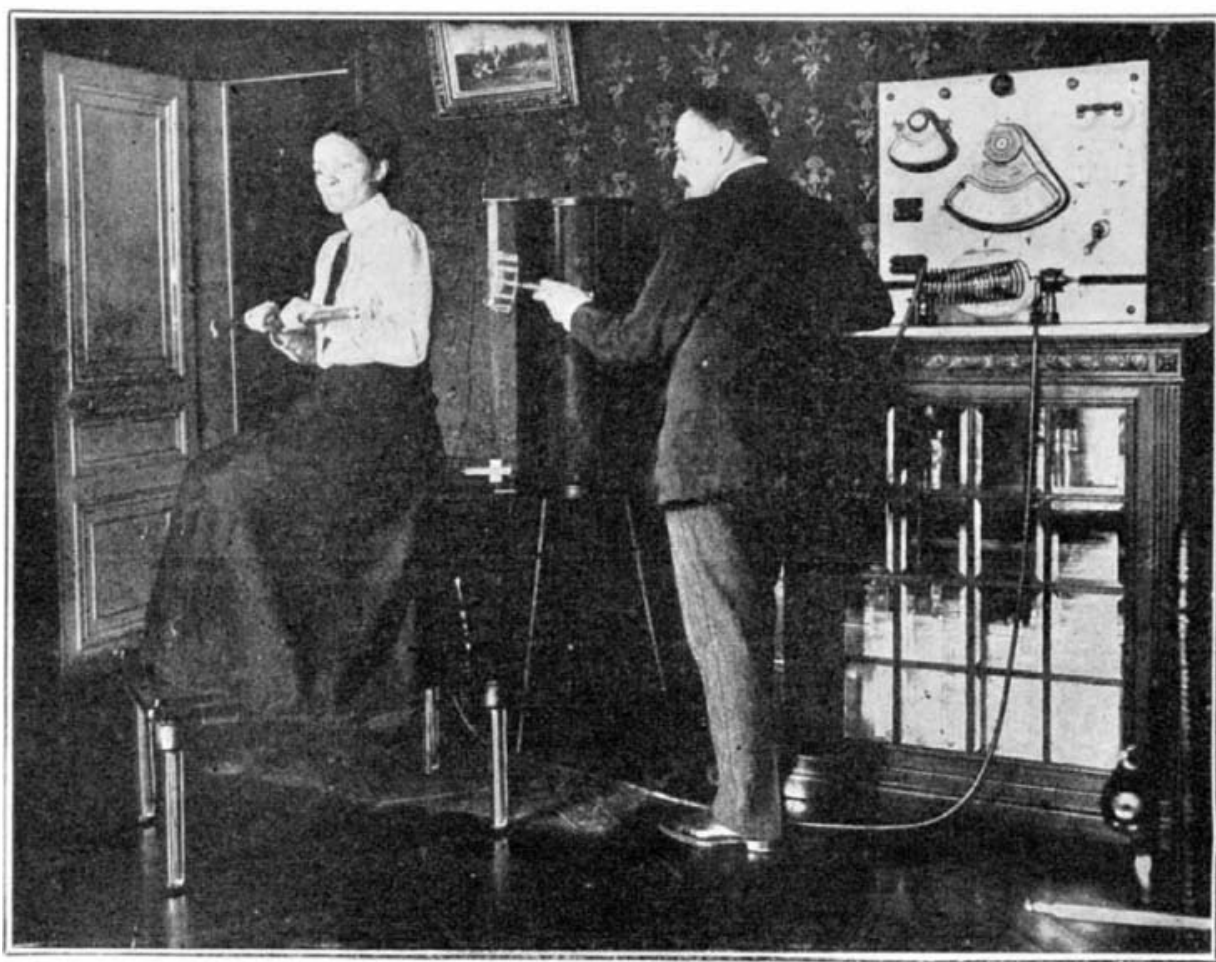

Application of high-frequency currents in the form of electric spray in cases of excessive arterial pressure.
And how would the biologist consider the electrifica-

In of children? ation certain fundamental ideas; differences regarding these ideas have been only in nomenclature. When the world was young the three Fates were spoken of. The three modern Fates, fully as inexorable as those of mythology, are heredity, environment, and function. And now, as ever, this is bestowed upon humankind the saving gift of will by which, so long as man respects the fates, he may be a coefficient in the working out of his own destiny. Only that will is normal which realizes its limitations and understands that if it is to be effective it must co-operate with rather than flaunt the Fates. Heredity, environment and function work even in most intimate interrelation; that will were indeed vast which would undertake to disturb such harmony.

Heredity is not easily modified; its manifestations are the result of the working of natural laws through many generations; any experimentation by which it were planned to effect a radical change in its phenomena were most ill advised.

Environment presents the external relations to which the body's internal relations (its functioning) must be rightly adjusted, if there is to be normal living. It were abnormal indeed, and nowise conformable with natural processes to force children for a few hours in the twentyfour into such a man-made environment as that in which electric waves of high frequency and high potency are generated. Here were an exhibition of perverted will snapping its fingers in the face of fate and as certainly inviting Promethean disaster.

We have seen how function is meddled with by this use of electricity. How careful should we be in employing this force, the essential nature of which we comprehend hardly at all, not much better to-day than did Volta and Galvani. In their day it was imagined the secret of the origin of life had been found, and men spoke of the vital principle and the spark of life. But these terms were after all really explanatory of nothing.

We know electricity only by its behavior, which is oftentimes terribly destructive. It may, in our present knowledge of it, affect the human economy in a way altogether unfortunate. Electrifying children were a perversion quite akin to the foolishness of "doping" normal individuals by the inhalation of pure oxygen, which gas is appropriate for the healthy only in its mixture with nitrogen as the environing atmosphere to which living creatures have throughout the ages become accustomed.

What is desirable for us is creatures (men and women and children) natural to our era. Monstrosities and giants and mastodons and ichthyosauri were very well in the geological age to which they were conditioned. Possibly, on the other hand, future aeons will present conditions appropriate for the evolution of supermen and superwomen; but this will come to pass not in months or in years, but only in many thousands of years. Even the noble science of eugenics cannot force the process.

Wells has written a story, "The Food of the Gods." By means of this food babies were nourished to the degree that developed into giants the height of trees; they were most unhappy because there were no houses properly proportioned for them to live in, no beds they could rest in, and so forth. Some rats managed to get hold of this food and grew enormousy. Rats are unpleasant enough as it is-but rats the size of sheep! Some wasps also imbibed this food, and became the size of Easter hats! A most unpleasant state of things developed; the only solution of the difficulty was a return to natural conditions.

This parable teaches us that every interference with nature causes not only the looked for effects. but also others, full of dangerous possibilities. 